\title{
Localized Osteosarcoma
}

National Cancer Institute

\section{Source}

National Cancer Institute. Localized Osteosarcoma. NCI Thesaurus. Code C7780.

A non-disseminated osteosarcoma. 